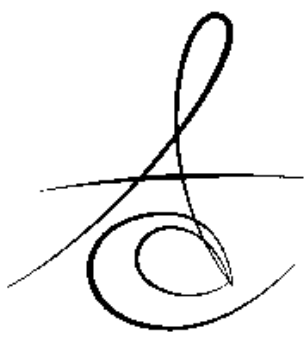

\title{
DISTINGUISHING HARD AND SOFT TISSUE FACIAL MORPHOLOGY AMONG CLASS I AND CLASS III CHILDREN: A CEPHALOMETRIC ASSESSMENT
}

\section{SINIF I VE SINIF III İLIŞ̧İLİ ÇOCUKLARDAKİ SERT VE YUMUŞAK DOKU YÜZ MORFOLOJİSİ FARKLILIKLARI: SEFALOMETRİK İNCELEME}

\author{
Prof. Dr. Nihat KILIÇ ${ }^{*}$ \\ Uzm.Dr. Gülhan ÇATAL ${ }^{* * *}$
}

\author{
Prof. Dr. Hüsamettin OKTAY** \\ Doç. Dr. Mevlüt ÇELIKOĞLU****
}

Makale Kodu/Article code: 3228

Makale Gönderilme tarihi: 22.12.2016

Kabul Tarihi: 02.02.2017

\section{ABSTRACT}

Aim: To assess the sagittal soft and hard soft tissue morphology of growing Class III patients in comparison with a Class I control subjects.

Materials and Methods: Forty-one female children with Class III malocclusion and 30 Class I female children were included in the study. Eight linear and 6 angular measurements were made on lateral cephalograms to evaluate soft tissue and skeletal characteristics.

Results: The subjects with Class III malocclusion showed a retrusive maxilla (A-y distance, 48.52 \pm 2.53 ) and upper lip (Ss-y distance, 64.14 13.26 ), a protrusive mandible (B-y distance, 56.15 \pm 5.49 ) a prominent chin (Pog'-y distance, 70.65 \pm 6.87 ), retroclined lower incisors (IMPA, 87.14 \pm 5.68 ), and increased vertical dimensions (SN-GoMe, 36.49 \pm 5.29 ) compared to control subjects.

Conclusions: Our findings indicated that soft and hard tissue characteristics of Class III subjects are distinct from Class I subjects in the middle region and lower third of the face. Orthopedic traction of mid-face arguably started earlier as a first treatment protocol to obtain balanced facial profile in Class III subjects.

Keywords: Soft tissue profile, cephalometry, Class III malocclusion, Class I occlusion

\section{öz}

Amaç: Bu çalışmanın amacı Sınıf III ilişkiye sahip çocukların sert ve yumuşak doku yüz morfolojisini Sınıf I ilişkiye sahip kontrol bireyleri ile karşılaştırmaktır.

Gereç ve Yöntem: Bu çalışma Sınıf III maloklüzyonlu 41 ve Sınıf I oklüzyonlu 30 bayan çocuğu içermektedir. Bu bireylerin sert ve yumuşak doku karakteristiklerinin incelenmesi için sefalometrik filmler üzerinde 8 linear ve 6 açısal ölçüm yapılmıştır.

Bulgular: Kontrol grubundaki bireylerle karşılaştırıldığında, Sınıf III maloklüzyonlu bireylerin retrüziv üst çene ve üst dudak, protruziv bir alt çene ve belirgin çene ucu, retrokline alt kesici dişler ile artmış dik yön boyutlara sahip oldukları görülmüştür.

Sonuç: Bu çalışmanın bulguları, Sınıf III bireylerin orta ve alt yüz bölgesindeki sert ve yumuşak doku yüz karakterlerinin Sınıf I bireylerden farklı olduğunu göstermektedir. Sınıf III bireylerde dengeli bir yüz profile elde etmek için, maksiller protraksiyon ilk tedavi protokolü olarak daha erken başlatılmalıdır.

Anahtar Kelimeler: Yumuşak doku profili, sefalometri, Sınıf III maloklüzyon, Sınıf I oklüzyon

\section{INTRODUCTION}

Class III malocclusion is a complex and one of the most difficult problems encountered clinically. The patients with Class III malocclusion may a retrusive or deficient maxilla, a larger or anteriorly positioned mandible, or combination of both. ${ }^{1}$ Class III subjects may protrusive maxillary and/or retrusive mandibular dentition. However, an obvious consequences of a Class III malocclusion is undesirable facial esthetics. ${ }^{1}$

*Department of Orthodontics, Faculty of Dentistry, Atatürk University, Erzurum.

${ }^{* *}$ Department of Orthodontics, Faculty of Dentistry, Istanbul Medipol University, Istanbul.

*** Private Practice, Kocaeli

${ }^{* * * *}$ Department of Orthodontics, Faculty of Dentistry, Akdeniz University, Antalya

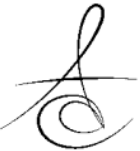


Primary goals of orthodontic treatment in subjects with Class III maloclusion are to obtain a balanced facial esthetics and an occlusion. Holdaway ${ }^{2}$ emphasized esthetic concerns of the patients after orthodontic treatment.

Possible abnormalities in hard tissue structures of the face could be masked or exaggerated by the soft tissues. In other words, soft tissue architecture does not always reflect the underlying dentoskeletal profile. Soft tissue morphology of the subjects with Class III malocclusion has been investigated in several clinical studies by means of thin-plate spline analysis, finite element morphometry, 3D analysis or cephalometric evaluations. ${ }^{3-7}$

Cephalometry is the most important and the most widely used diagnostic tool in orthodontics. Cephalometric images from hard ${ }^{8}$ and soft tissues ${ }^{9}$ are comparable with those obtained from 3D system. An important shortcoming of the cephalometric studies is that they are generally focused on dentoskeletal structures.

More female patients were reported to focus on esthetic desires, while male patients tended to emphasize functional needs. ${ }^{10}$ Little attention has been given to soft tissue facial profile of female subjects.

The purpose of this study is to draw attention to facial appearance of females with Class III malocclusion, and to underline especially the importance of soft tissue morphology in orthodontic treatment planning.

\section{MATERIALS AND METHODS}

This retrospective study was carried out on cephalometric head films of the study and control subjects. The films were chosen from the achieve files in Orthodontic Department of Dentistry Faculty, Atatürk University, according to the selection criteria mentioned below. Local ethics committee approved this study. All subjects are Turkish children with Turkish grandparents.

Because most of the subjects seeking orthodontic treatment are the females, this study was carried out on female children. Forty-one female children having dental and skeletal Class III relationship and anterior cross bite were included to study group (Figure 1).
Control group consisted of thirty subjects having skeletal and dental Class I relationship and no or minimal crowding (2-4 mm) and no crossbites (Figure 2).

All of the subjects in the treatment and control groups were in late mixed or early permanent dentition stages, and their mean ages were 11.83 and 11.19 years, respectively. Skeletal age and menarche were not taken into consideration in the selection. The study and control groups were matched with respect to chronological age.

The children were excluded as study subjects if they had previous history of previous orthodontic treatment, cleft-lip and palate, and systemic disorder.

All of the cephalometric films were taken using the same cephalostat in standard manner. The films were scanned with an Epson Expression 1860 Pro scanner and the resulting images (100 per cent) were digitized and measured using Quick Ceph 2000.

On the cephalometric images, 8 linear and 6 angular parameters were measured in order to determine the differences in soft and hard tissue facial profiles of the groups (Figures 3 and 4 ). ${ }^{11}$

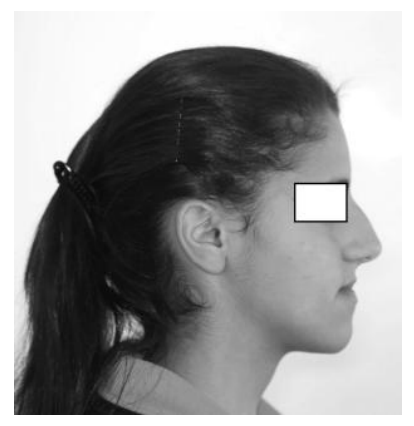

Figure 1. Facial appearance of a case with Class III malocclusion

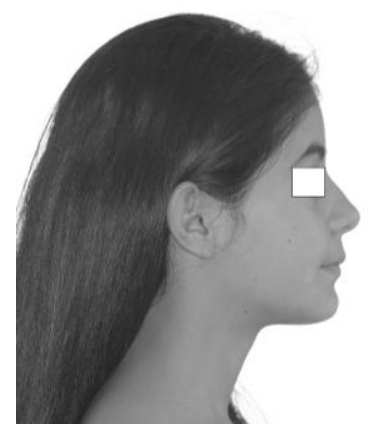

Figure 2. Facial appearance of a case with Class I occlusion. 


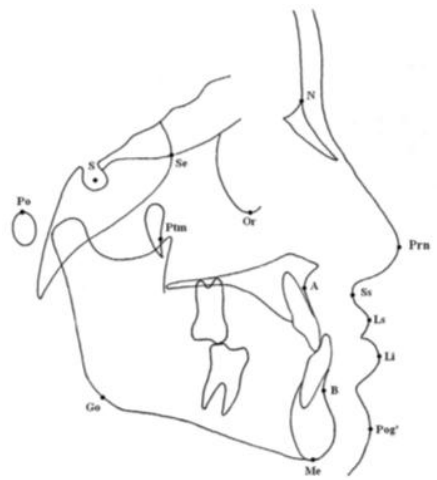

Figure 3. Landmarks used in the study: $\mathrm{S}$, sella; $\mathrm{N}$, nasion; Or, orbitale; Ss, sulcus superior; Ls, labial superior; Li, labial inferior; Pog', soft tissue pogonion; $A$, point $A ; B$, point $B$; Me, menton; Go, gonion; Po, porion; Se, intersection of the greater wing of sphenoid bone with the floor of anterior cranial fossa; Ptm, the most inferior and posterior point on the anterior outline of pterygo-maxillary fissure; and Prn, pronasale.

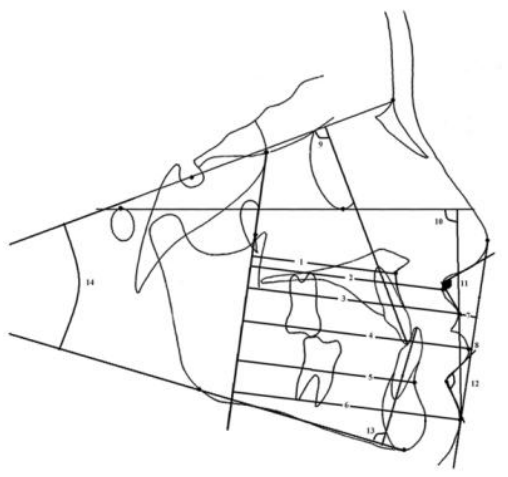

Figure 4. Reference planes and linear and angular measurements used in the present study:

$y$-axis (PMV plane): A line passing through the Se and Ptm points.

E line (Ricketts' aesthetic line): A line passing through nose tip (Prn) and soft tissue pogonion (Pog').

Mandibular plane: A plane passing through gonion and menton.

Frankfort horizontal plane: A plane passing through porion and orbitale.

(1) A - y, (2) Ss $-y_{1}$ (3) Ls - y, (4) Li - y, (5) B - y, (6) Pog' $-y_{1}$ (7) $L s-E_{1}(8) L i-E_{1}$

(9) U1 - SN, (10) Z angle, (11) nasolabial angle, (12)

labiomental angle, (13) IMPA,

\section{Statistical Analysis}

Houston $^{12}$ analysis was done to assess the reliability of the measurements. Homogeneity of the measurements was checked by means of KolmogorovSmirnov test. Because all parameters showed a normal distribution, between-group comparisons of the parameters were carried out by means of a Student's t test.

\section{RESULTS}

Houston $^{12}$ analysis showed high reliability of the measurements for all parameters. Means of chronological ages of the groups showed no significant difference between the groups. The results of Student's t test comparing the measurements for the groups are shown in Table 1 . The findings of Table 1 are as follows: The parameters showing the anteroposterior position of maxilla and surrounding soft tissues (point A, sulcus superior, and upper lip to PMV distances) were significantly smaller, while the parameters regarding mandible (point $B$ and soft tissue pogonion to PMV distances) were significantly greater in the Class III subjects than the controls. The distance from upper lip to E-line and nasolabial, labiomental, Z, and SN-GoMe angles were also significantly larger in the study group. One of the most remarkable findings of the Class III subjects was diminished lower incisor inclination.

Table 1. Results of Student's t test showing between-group comparisons.

\begin{tabular}{|c|c|c|c|c|c|}
\hline \multirow[b]{2}{*}{ Parameters } & \multicolumn{2}{|c|}{ Class III Group } & \multicolumn{2}{|c|}{ Control Group } & \multirow[b]{2}{*}{$\begin{array}{c}\mathrm{P} \\
\text { value }\end{array}$} \\
\hline & Mean & $\begin{array}{c}\text { Std. } \\
\text { Deviation }\end{array}$ & Mean & $\begin{array}{c}\text { Std. } \\
\text { Deviation }\end{array}$ & \\
\hline A-y (mm) & 48.52 & 2.53 & 51.10 & 2.79 & 0.000 \\
\hline Ss-y (mm) & 64.14 & 3.26 & 66.17 & 3.45 & 0.003 \\
\hline Ls-y (mm) & 68.12 & 3.89 & 70.37 & 4.21 & 0.006 \\
\hline Li-y (mm) & 71.27 & 5.36 & 69.97 & 4.79 & 0.205 \\
\hline B-y (mm) & 56.15 & 5.49 & 52.56 & 4.90 & 0.001 \\
\hline Pog'-y (mm) & 70.65 & 6.87 & 67.28 & 6.19 & 0.012 \\
\hline Ls-E (mm) & -5.88 & 2.40 & -2.51 & 2.10 & 0.000 \\
\hline Li-E (mm) & -1.67 & 2.79 & -0.89 & 2.41 & 0.141 \\
\hline U1-SN (mm) & 100.21 & 5.75 & 101.93 & 4.88 & 0.112 \\
\hline $\mathrm{Z}$ angle $\left({ }^{\circ}\right)$ & 80.25 & 5.78 & 76.84 & 4.61 & 0.002 \\
\hline $\begin{array}{l}\text { Nasolabial } \\
\text { angle }\left(^{\circ}\right)\end{array}$ & 112.46 & 9.99 & 106.41 & 9.51 & 0.003 \\
\hline $\begin{array}{l}\text { Labiomental } \\
\text { angle }\left(^{\circ}\right)\end{array}$ & 137.79 & 9.66 & 124.08 & 12.10 & 0.000 \\
\hline IMPA (०) & 87.14 & 5.68 & 95.89 & 5.01 & 0.000 \\
\hline SN-GoMe (0) & 36.49 & 5.29 & 33.30 & 4.12 & 0.001 \\
\hline
\end{tabular}

\section{DISCUSSION}

This cephalometric study aimed to evaluate the differences in soft tissue facial profiles of the subjects with Class I or Class III malocclusion. Although 3D evaluations gained great interest in recent years, 2D

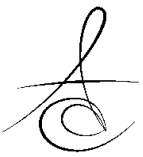


cephalometry has maintained its importance in orthodontic diagnosis and treatment planning. In a recent paper, Yitschaky and co-workers ${ }^{8}$ compared the $3 D$ and 2D images of human dry skulls and found no difference between conventional analysis and 3D analysis for the most of measurements. Incrapera et $\mathrm{al}^{9}$ found insignificant differences between twodimensional and three dimensional analysis.

The results of the present study showed that the children with Class III malocclusion had an underdeveloped upper jaw and a retrusive upper lip. In other words, the subjects with Class III malocclusion had maxillary hypoplasia and a concave soft tissue facial profile. It is well known that skeletal maxillary retrusion constitutes a major component of Class III pattern. ${ }^{1,13}$

Soft tissue facial profile of the patients with maxillary retrusion was studied in a few studies. Singh et $\mathrm{al}^{14}$ compared soft tissue morphologies of the children with Class III and Class I malocclusions, and found that half of the linear and three-fourths of the angular parameters differed statistically. According to these authors, soft tissue dynamics may contribute to the development of Class III malocclusions during early postnatal development. In a recent paper, Chang et $\mathrm{al}^{15}$ revealed that developmental shortening of palatomaxillary complex in Class III subjects caused a retrognathic appearance of midface. Rabie and $\mathrm{Gu}^{16}$ stated that pseudo Class III malocclusions were characterized by retrusive upper lip.

Our results showed that the subjects with class III malocclusion had larger mandibles (B-y distance) and prominent soft tissue pogonion. In accordance with our results, several studies ${ }^{1,13,16}$ showed that there was a tendency of more horizontal growth pattern in the mandibles of Class III subjects.

The results of the present study also indicated that a prominent lower lip was present in the Class III subjects, although it was found as statistically insignificant. However, labiomental angle increased significantly in Class III group. These results are comparable with the findings of other studies. ${ }^{1,15}$

We also found that Class III group had significantly increased vertical dimensions. Similar findings were shown in previous studies. ${ }^{2}$ According to Spalj et al, $^{13}$ Class III subjects with maxillary retrognathia have an increased vertical growth pattern. In a cross sectional study, Bacetti et al ${ }^{17}$ studied craniofacial characteristic of 1091 class III children and found a growth trends toward accentuated Class III profile and increased vertical facial dimension towards the late developmental stages.

Our results clearly showed that soft tissue dynamics might contribute to the development of Class III malocclusions during early postnatal development. In other words, the data obtained in the present study soft tissue structure of the class III subjects is a contributing factor in development of features of class III malocclusion, although this relationship has complexity in nature. Supporting our results, Kasai ${ }^{18}$ noted that there was a strong but complex relationship between the hard and soft tissue profile changes.

Patients and orthodontists have considered soft tissue facial profile as an imperative objective of the orthodontic/orthopedic therapy in patients with Class III malocclusion. In the present study, Class III children showed more retrognathic facial appearance in the maxillary and upper lip area. Findings of the recent studies on three-dimensional face analyses of the children aged $5-6^{19}$ years or 7-8 years ${ }^{4}$ showed that Class III faced children mainly had concave facial profile, retruded maxilla, protruded mandible, retrusive mid-face restricted area compared to the Class I faces.

According to the our results, forward growth stimulation and consequently moving the maxilla forward with external force exerted by orthopedic treatment methods such as maxillary protraction, accompanied by corresponding forward movement of the soft tissue of the midface, should be considered in treatment planning of Class III malocclusion in early stages of dentition. ${ }^{20,21}$

\section{CONCLUSIONS}

Our findings indicated that soft and hard tissue characteristics of Class III subjects are distinct from Class I subjects in the middle region and lower third of the face. Orthopedic traction of mid-face arguably started earlier as a first treatment protocol to obtain balanced facial profile in Class III subjects.

Nihat Kılıc, ORCID ID: 0000-0002-1753-1380 Hüsamettin Oktay, ORCID ID: 0000-0001-7862-2983 


\section{KAYNAKLAR}

1. Guyer EC, Ellis EE, McNamara JA, Behrents RG. Components of Class III malocclusion in juveniles and adolescents. Angle Orthod 1986;56:7-30.

2. Holdaway RA. A soft-tissue cephalometric analysis and its use in orthodontic treatment planning. Part I. Am J Orthod. 1983;84:1-28.

3. Alves PV, Zhao L, Patel PK, Bolognese AM. Threedimensional facial surface analysis of patients with skeletal malocclusion. J Craniofac Surg 2009;20:290-6.

4. Krneta B, Zhurov A, Richmond S, Ovsenik M. Diagnosis of Class III malocclusion in 7- to 8-yearold children--a 3D evaluation. Eur J Orthod 2015;37:379-85.

5. Božič M, Kau CH, Richmond S, Ovsenik M, Hren NI. Novel method of 3-dimensional soft-tissue analysis for Class III patients. Am J Orthod Dentofacial Orthop 2010;138:758-69.

6. Bavbek NC, Tuncer BB, Tuncer C, Gungor K, Ozkan C, Arslan E, Altinova AE, Akturk M, Toruner FB. Cephalometric assessment of soft tissue morphology of patients with acromegaly. Aust Orthod J. 2016;32:48-54.

7. Mishima K, Shiraishi M, Kawai $Y$, Umeda H, Nakano $\mathrm{H}$, Ueyama $\mathrm{Y}$. Characteristics of Posed Smiles for Class III Female Patients Before and After Osteotomy Using Principal Component Analysis. J Craniofac Surg. 2016 Sep 19. [Epub ahead of print]

8. Yitschaky O, Redlich M, Abed Y, Faerman M, Casap $\mathrm{N}$, Hiller N. Comparison of common hard tissue cephalometric measurements between computed tomography 3D reconstruction and conventional 2D cephalometric images. Angle Orthod 2011;81:13-8.

9. Incrapera $A K$, Kau $\mathrm{CH}$, English JD, McGrory K, Sarver DM. Soft tissue images from cephalograms compared with those from a 3D surface acquisition system. Angle Orthod 2010;80:58-64.

10. Lin SS, Lai JP, Yen YY, Chen IC, Kuo AH, Yeh IC. Investigation into the prediction accuracy of photocephalometry for skeletal Class III adult female patients treated with two-jaw surgery. J Dent Sci 2012;7:137-47.

11. Nanda RS, Meng H, Kapila S, Goorhuis J. Growth changes in the soft tissue facial profile. Angle Orthod 1990;60:177-90.
12. Houston WJ. The analysis of errors in orthodontic measurements. Am J Orthod 1983;83:382-90.

13. Spalj S, Mestrovic S, Lapter Varga M, Slaj M. Skeletal components of class III malocclusions and compensation mechanisms. J Oral Rehabil 2008;35:629-37.

14. Singh GD, McNamara JA, Lozanoff S. Finiteelement morphometry of soft tissue morphology in subjects with untreated Class III malocclusions. Angle Orthod 1999:69:215-24.

15. Chang HP, Lin HC, Liu PH, Chang CH. Midfacial and mandibular morphometry of children with Class II and Class III malocclusions. J Oral Rehabil 2005;32:642-7.

16. Rabie $A B, G u$ Y. Diagnostic criteria for pseudoClass III malocclusion. Am J Orthod Dentofacial Orthop 2000;117:1-9.

17. Baccetti T, Reyes BC, McNamara JA. Craniofacial changes in Class III malocclusion as related to skeletal and dental maturation. Am J Orthod Dentofacial Orthop 2007;132:171.e1- e12.

18. Kasai K. Soft tissue adaptability to hard tissues in facial profiles. Am J Orthod Dentofacial Orthop 1998;113:674-84.

19. Krneta B, Primožič J, Zhurov A, Richmond S, Ovsenik M.Three-dimensional evaluation of facial morphology in children aged 5-6 years with a Class III malocclusion. Eur J Orthod 2014;36:133-9.

20. De Clerck HJ, Proffit WR. Growth modification of the face: A current perspective with emphasis on Class III treatment. Am J Orthod Dentofacial Orthop 2015;148:37-46.

21. Kilic N, Catal G, Kiki A, Oktay H. Soft tissue profile changes following maxillary protraction in Class III subjects. Eur J Orthod 2010;32:419-24.

\author{
Yazışma Adresi \\ Dr. Nihat Kilic \\ Atatürk Üniversitesi Diş Hekimliği Fakültesi \\ Ortodonti Anabilim Dalı \\ 25240 Erzurum, TURKEY. \\ E mail: drnkilic@yahoo.com
}

